\title{
Latitude-dependent underestimation of microbial extracellular enzyme activity in soils
}

\author{
J. M. Gonzalez $・$ M. C. Portillo $\cdot$ M. Piñeiro-Vidal
}

Received: 9 April 2013/Revised: 25 April 2014/Accepted: 7 June 2014/Published online: 6 September 2014

(C) Islamic Azad University (IAU) 2014

\begin{abstract}
Decomposition of soil organic matter by microorganisms is a major process governing the carbon balance between soil and atmosphere which needs to be fully understood. Extracellular enzyme activity is often the limiting factor for microbial utilization of soil organic matter. Contrary to expectations, we observed that enzymatic activity rises at increasing temperatures in soils and sediments. Current climatic change will induce the increase of global mean temperatures, frequency of extreme heat events and soil temperatures during the next decades. The relevance of the increase in activity at high temperature is dependent on latitude. At latitudes around and below $40^{\circ}$ a significant number of days per year present high temperatures. Results suggest that the hydrolytic activity of microbial extracellular enzymes is currently underestimated mainly at medium and low latitudes where soil temperatures frequently reach high values (often above $40{ }^{\circ} \mathrm{C}$ ). This report contributes to understand (1) the hydrolysis of soil organic matter within a latitude-dependent scenario of global warming and (2) the role of microorganisms in processing soil organic matter and their influence in carbon cycling.
\end{abstract}

Keywords Extracellular enzyme activity · Global warming - Extreme heat events - Microbial activity . Latitude $\cdot$ Soil $\cdot$ High temperature

Electronic supplementary material The online version of this article (doi:10.1007/s13762-014-0635-7) contains supplementary material, which is available to authorized users.

J. M. Gonzalez $(\bowtie) \cdot$ M. C. Portillo · M. Piñeiro-Vidal Instituto de Recursos Naturales y Agrobiologia, Consejo Superior de Investigaciones Científicas, IRNAS-CSIC, Avda. Reina Mercedes 10, 41012 Sevilla, Spain e-mail: jmgrau@irnase.csic.es

\section{Introduction}

Carbon stock is much larger in soil than in the atmosphere (Conant et al. 2011; Davidson and Janssens 2006; Smith et al. 2008). The accumulation and utilization of organic matter in soils rules the carbon balance between terrestrial environments and atmosphere. Inputs from plant-derived carbon and outputs by decomposition and mineralization result in feedback mechanisms having major impacts on Earth́s climate (Conant et al. 2011; Davidson and Janssens 2006; Smith et al. 2008). Factors inducing changes to that equilibrium need to be understood for accurate predictive modeling and simulations (Davidson and Janssens 2006).

Organic carbon decomposition is mainly carried out by microorganisms (Conant et al. 2011; Whitman et al. 1998). Soils contain extremely diverse and abundant microbial communities (Curtis et al. 2002; Gonzalez et al. 2012). The production of extracellular hydrolytic enzymes by microorganisms is a primary mechanism for the decomposition of soil organic matter. These enzymes break down complex organic molecules releasing smaller molecules into the environment which can be assimilated and mineralized (Asmar et al. 1994; Madigan et al. 2003). The availability of different organic substrates regulates the production of these hydrolytic enzymes (Velasco-Ayuso et al. 2011). The activity of extracellular enzymes represents the rate-limiting step in processing soil organic matter and constitutes a direct indicator of microbial production (Asmar et al. 1994; Chróst 1992; Conant et al. 2011; Velasco-Ayuso et al. 2011). Extracellular enzyme activity is commonly used to assess the functional capacity of microbial communities (Allison and Treseder 2008).

Microbial extracellular enzymatic activity in soils is currently determined at or below $30{ }^{\circ} \mathrm{C}$ (Bradford et al. 
2010; Conant et al. 2011; Craine et al. 2010; Fierer et al. 2006). Generally, enzymatic activity shows maxima at a temperature slightly higher than the optimum for growth of a microorganism (Burton et al. 2002; Kube et al. 2013; Madigan et al. 2003; Tang et al. 2010). However, enzymatic activity sharply decreases at increasing temperatures beyond its optimum (Ise and Moorcroft 2006; Madigan et al. 2003). As a consequence, increasing temperatures above the experimental threshold for mesophiles (i.e., temperatures for optimum microbial activity and growth) should reflect highly diminished microbial enzymatic activities and consequently a decrease of the estimates for the expected decomposition of organic matter in soils (Conant et al. 2011; Davidson and Janssens 2006).

A few studies have pointed out the presence (Marchant et al. 2002, 2008) and potential role (Portillo et al. 2012; Santana et al. 2013) of thermophilic microorganisms in soils. This evidence suggests that soil thermophiles could show relevance decomposing organic $\mathrm{C}$ under periods of elevated temperature in nature. Further research on this point is required to fully realize the potential of microbial processes on $\mathrm{C}$ cycling under global increasing temperature scenarios.

The prediction of global processes and the consequences of climate change require a good understanding on the role of microorganisms and their activities (Conant et al. 2011; Craine et al. 2010; Davidson and Janssens 2006). Among other causes, temperature is a major factor influencing the microorganisms and microbial activity leading to the decomposition of soil organic matter (Craine et al. 2010; Parmesan and Yohe 2003). Although trends in mean temperature conditions are clearly important in understanding the effects of global warming, accumulating facts suggest that changes in the frequency distribution of extreme temperature events may also have far-reaching implications (IPCC 2007; Jentsch et al. 2007). Current evidence indicates that the frequency of hot temperatures in soils (e.g., above $40{ }^{\circ} \mathrm{C}$ ) is expected to increase along the next decades.

The aim of this study was to comparatively evaluate microbial extracellular enzyme activity over a wide range of temperature conditions focusing on the effect of high temperatures. The occurrence of high temperatures at different latitudes is also analyzed to assess the potential relevance of the findings. This report contributes to a better understanding of the influence of temperature on extracellular enzyme activity by microorganisms in terrestrial environments and the temperature-dependent functionality of soil microbial communities. This study was performed during 2010-2011 at the Institute of Natural Resources and Agrobiology of Seville, Spanish Council for Research, in Seville, Spain.

\section{Materials and methods}

\section{Sampling}

Samples were collected from different environments under sterile conditions. Sampling site A corresponds to a clay soil in Southwestern Spain (Seville; location $37^{\circ} 21.02^{\prime} \mathrm{N}$ $5^{\circ} 59.34^{\prime} \mathrm{W}$, altitude $5 \mathrm{~m}$ ) with soil temperatures ranging from $10{ }^{\circ} \mathrm{C}$ to over $60{ }^{\circ} \mathrm{C}$. Sandy sediments were from a wetland at Doñana National Park (DNP; Southwestern Spain). These samples were collected from the edge of three freshwater ponds: "La Dulce" (Sampling site B) (location $36^{\circ} 58.84^{\prime} \mathrm{N} 6^{\circ} 29.23^{\prime} \mathrm{W}$, altitude $3 \mathrm{~m}$ ), “Santa Olalla" (Sampling site C) (location $36^{\circ} 58.84^{\prime} \mathrm{N} 6^{\circ} 28.91^{\prime} \mathrm{W}$, altitude $5 \mathrm{~m}$ ) and "Zahillo" (Sampling site D) (location $36^{\circ} 59.21^{\prime} \mathrm{N} 6^{\circ} 30.43^{\prime} \mathrm{W}$, altitude $2 \mathrm{~m}$ ). Sandy soil (Sample site E) from DNP around "Santa Olalla" Pond was also collected. Samples from a meadow in Cambridge (United Kingdom) (Sampling site F) (location $52^{\circ} 11.92^{\prime} \mathrm{N}$ $0^{\circ} 7.07^{\prime} \mathrm{E}$, altitude $37 \mathrm{~m}$ ) were collected. Triplicate samples were collected from the surface except when noticed otherwise. Including in this study, different types of soils and sediments contributes to determine whether the observed results of extracellular enzymatic activity over a wide range of temperatures corresponds to a general pattern. See supplementary material for a more detailed description of the methods.

\section{Enzymatic assays}

In situ protease and glucosidase activities in natural samples were determined using fluorogenic substrates (EnzCheck green fluorescence protease assay kit, E6638; and fluorescein diglucoside, F2881; Invitrogen, Carlsbag, CA, USA) without additional treatments. Samples were suspended in phosphate buffer $(\mathrm{pH}$ 7.0). All samples were processed in triplicate and controls without sample, controls without fluorogenic substrate and autoclaved controls were carried out. Reactions $(50 \mu \mathrm{l})$ were prepared in 96-well microplates with 1-2 mg sample per well. A final substrate concentration of $0.1 \mathrm{mM}$ was used in this study (Marx et al. 2001). Reactions were incubated in an optical thermocycler (iQ iCycler, Bio-Rad, Hercules, California, USA) and final activity was expressed as the slope of the linear increase of fluorescence produced during the reaction time per dry weight at each temperature. Temperatures were assayed at $5{ }^{\circ} \mathrm{C}$ intervals from 5 to $95{ }^{\circ} \mathrm{C}$. The proteolytic substrate was stable within this range and the glucoside substrate showed certain instability. Other fluorogenic substrates targeting different enzymatic activities, such as phosphatases and esterases, were tested but they were unstable at elevated temperatures. ANOVA tests were 
used to determine significant differences among samples (Sokal and Rolhf 1995).

Bacterial cultures were used to evaluate enzymatic activity from known bacteria (mesophile and thermophile). Escherichia coli $\mathrm{K} 12$ was a mesophilic microorganism and two soil bacterial isolates, Brevibacillus sp. strain 10 (CECT7629) and Ureibacillus sp. strain 12 (CECT7628) (Portillo et al. 2012) were chosen as thermophilic bacteria. Optimum growth temperatures were 55 and $60{ }^{\circ} \mathrm{C}$ for strains 10 and 12, respectively. Cultures were grown in nutrient broth composed by beef extract $\left(3 \mathrm{~g} \mathrm{l}^{-1}\right)$, peptone $\left(5 \mathrm{~g} \mathrm{l}^{-1}\right)$ and sodium chloride $\left(5 \mathrm{~g} \mathrm{l}^{-1}\right)$.

\section{Temperature sensitivity}

Temperature sensitivity was studied using the parameter $\mathrm{Q}_{10}$ which was estimated according to Stone et al. (2012) as $\mathrm{Q}_{10}=\exp ($ slope $\times 10)$. The slopes represent the change of activity for each sample at the temperature range being considered (Stone et al. 2012). $Q_{10}$ constitutes the change of activity resulting from a temperature variation of $10{ }^{\circ} \mathrm{C}$ and it is generally expected to obtain results of $\mathrm{Q}_{10}$ around 2 in biological systems (Davidson and Janssens 2006; Madigan et al. 2003). $Q_{10}$ is probably the most frequently used parameter to evaluate the effect of temperature on biological processes and it is widely used in global modeling efforts (Conant et al. 2011; Davidson and Janssens 2006; Stone et al. 2012).

\section{Temperature record}

Temperature records were obtained at the National Oceanic and Atmospheric Administration (Washington DC, USA; http://www7.ncdc.noaa.gov/CDO/cdoselect.cmd). The number of days with a maximum temperature of $30{ }^{\circ} \mathrm{C}$ or above was counted for each year at a number of locations covering the range of latitude from $70^{\circ} \mathrm{N}$ to $70^{\circ} \mathrm{S}$. According to our measurements, air temperatures of $30{ }^{\circ} \mathrm{C}$ and above resulted in soil temperatures above $40{ }^{\circ} \mathrm{C}$.

\section{Results and discussion}

Soils are among the systems with highest microbial diversity. Microbial communities in soils are highly complex and a large number of different microorganisms thrive in these environments adapting to this highly heterogeneous habitat (Curtis et al. 2002; Torsvik et al. 2002). Decomposition of soil organic matter by microorganisms is a major process governing $\mathrm{C}$ stocks (Davidson and Janssens 2006). Climate change expectancies suggest increasing global temperatures. Even more importantly, an increase in the frequency and intensity of extreme heat events has also been predicted (IPCC 2007). However, the effect of temperature on microbial activity remains to be fully understood (Conant et al. 2011). Extracellular hydrolysis of polymers is generally limiting the rate of organic matter decomposition by soil microorganisms (Allison and Treseder 2008; Conant et al. 2011; VelascoAyuso et al. 2011). In this study, the potential relevance of high temperature on extracellular enzyme activity by soil microorganisms is analyzed.

In natural samples collected at different temperatures and from different locations, protease activity maxima were detected from 45 to $75^{\circ} \mathrm{C}$ and the maxima of glucosidase activity were detected around $70{ }^{\circ} \mathrm{C}$ (Fig. 1a-f). Above these threshold temperatures, enzymatic activity started to decline. In natural samples, distinct microorganisms contributed differentially to the activity detected at each temperature (Bradford et al. 2010; Conant et al. 2011). Protease and glucosidase activities from $E$. coli showed peaks of maximum activity at 45 and $50{ }^{\circ} \mathrm{C}$, respectively (Fig. 1g, h) which corresponded to the expected results according to previous reports (Burton et al. 2002; Kube et al. 2013; Madigan et al. 2003; Tang et al. 2010). Thermophilic isolates showed peaks of maximum glucosidase activity at 75 and $60{ }^{\circ} \mathrm{C}$ for strains 10 and 12 , respectively (Fig. 1g). Maximum protease activity was detected at $65^{\circ} \mathrm{C}$ for thermophilic strains 10 and 12 (Fig. 1h).

Temperature sensitivity using $\mathrm{Q}_{10}$ were in the range 1.28-2.23 (Table 1) for the proteolytic activity in natural samples (mean 1.67; SD 0.28) over a range of $60{ }^{\circ} \mathrm{C}$. Glucosidase activity in natural samples showed $\mathrm{Q}_{10}$ values around 2.1. In monospecific cultures, protease and glucosidase activities were in the ranges 1.58-2.68 and 1.56-2.31, respectively, which included mesophilic (i.e., E. coli) and thermophilic microorganisms (Table 1).

Figure 2 shows the average number of days reaching air temperatures equal to or above $30{ }^{\circ} \mathrm{C}$ for a variety of locations including the range of latitudes from $70^{\circ} \mathrm{N}$ to $70^{\circ} \mathrm{S}$. The observed Gaussian distribution indicates that locations within the $40^{\circ} \mathrm{N}-40^{\circ} \mathrm{S}$ range experience a significant number of days with high temperature. At low latitudes, below $20^{\circ}$, over 200 high temperature days per year have been recorded. For example, an average of more than 100 days per year reached $30{ }^{\circ} \mathrm{C}$ or more at Seville $\left(37^{\circ} \mathrm{N}\right)$ which represents a conservative site at the limit of latitude within the $40^{\circ} \mathrm{N}$ to $40^{\circ} \mathrm{S}$ range. Medium to low latitude zones are prone to hot summers and a predicted increase of extreme heat events (IPCC 2007; Jentsch et al. 2007) will result in frequent soil temperatures well above $40{ }^{\circ} \mathrm{C}$. At medium and low latitudes, areas with poor, or partial, vegetation can reach over $60{ }^{\circ} \mathrm{C}$ at soil surface and well over $40{ }^{\circ} \mathrm{C}$ a few centimeters below ground (Portillo 

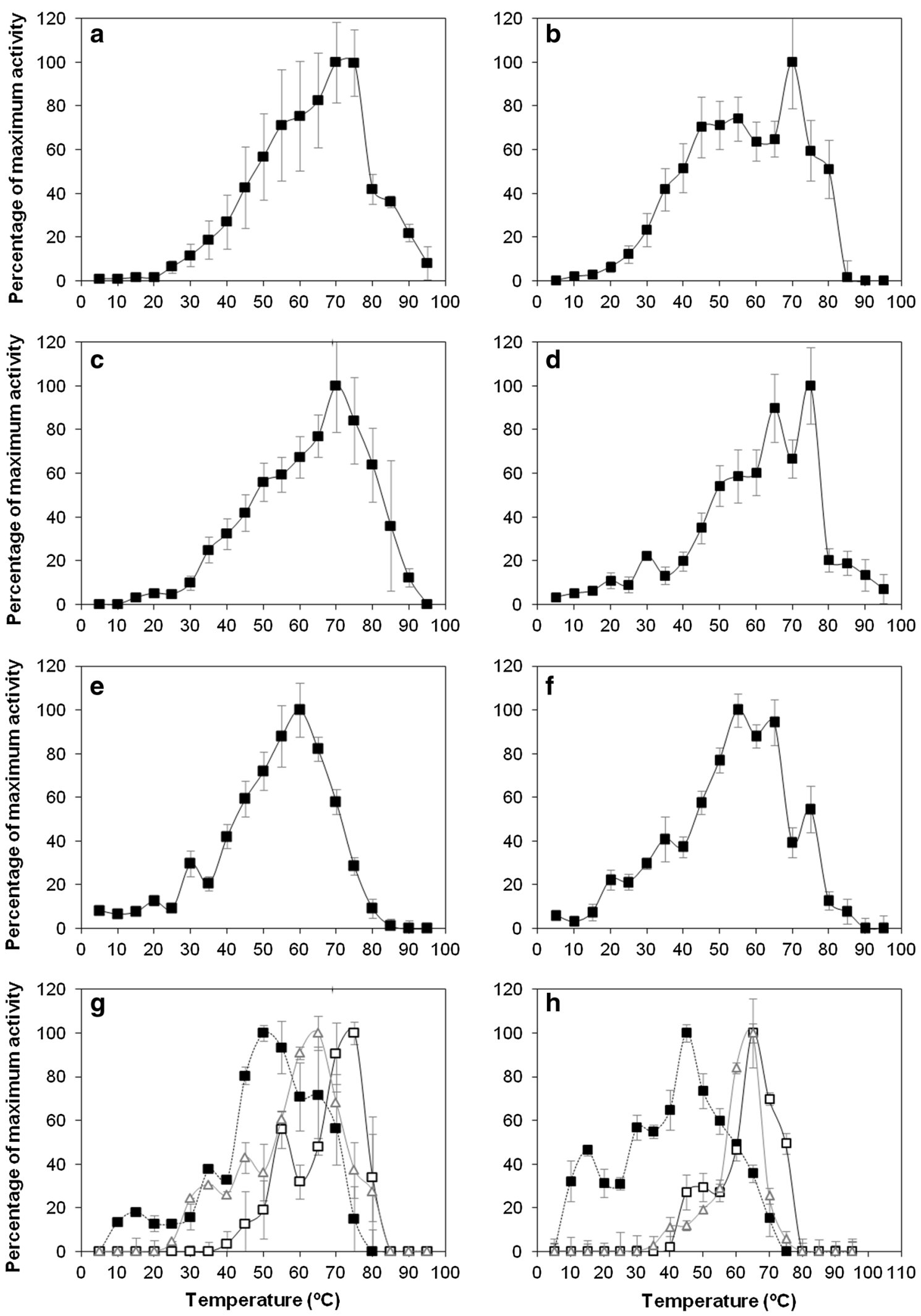
4Fig. 1 Glucosidase $(\mathbf{a}, \mathbf{b}, \mathbf{g})$ and protease $(\mathbf{c}-\mathbf{f}, \mathbf{h})$ activities from natural samples $(\mathbf{a}-\mathbf{f})$ and cultures $(\mathbf{g}, \mathbf{h})$ at a wide spectrum of temperatures (from 5 to $95{ }^{\circ} \mathrm{C}$ ). Natural samples correspond to: a soil sample at an outlying area of Seville, sampling site A collected at $28.0{ }^{\circ} \mathrm{C}$, b sampling site A collected at $28.5^{\circ} \mathrm{C}$, c sediments from DNP, "Santa Olalla" Pond, sampling site C, collected from the surface at $23.9{ }^{\circ} \mathrm{C}$, d sediments from DNP, "La Dulce" Pond, sampling site B, collected from the surface at $16.3{ }^{\circ} \mathrm{C}$, e soil from DNP, sampling site E, collected from the surface at $12.6{ }^{\circ} \mathrm{C}, \mathbf{f}$ soil from Cambridge, sampling site $\mathrm{F}$, collected at $2{ }^{\circ} \mathrm{C}$. Glucosidase (g) and protease (h) activities in cultures of E. coli (filled squares, dashed line), Brevibacillus sp. strain 10 (open squares, continuous line) and Ureibacillus sp. strain 12 (open triangles, gray line). Bars indicate SD et al. 2012). Desserts can easily get above $90{ }^{\circ} \mathrm{C}$ (McCalley and Sparks 2009). High latitudes (above $40^{\circ} \mathrm{N}$ and $\mathrm{S}$ ) showed practically no days at $30{ }^{\circ} \mathrm{C}$ (Fig. 2). High latitudes (above $40^{\circ} \mathrm{N}$ and $\mathrm{S}$ ) present a cold climate and soil temperatures only sporadically reach those elevated temperatures (Marchant et al. 2002, 2008). These results confirm a clear latitude dependence on the potential relevance of microbial extracellular enzyme activity.

Herein, the detection of hydrolytic activities in the environment has been carried out over a wide range of temperatures $\left(5-95^{\circ} \mathrm{C}\right)$ unlike previous studies that determined hydrolytic activities at mesophilic temperatures,
Table 1 Temperature of maximum enzymatic activity, $\mathrm{Q}_{10}$, and in situ temperature for the samples and cultures analyzed during this study a Samples collected at a different time during a day

${ }^{b}$ Centimeters below soil surface

${ }^{\mathrm{c}}$ Incubation temperature

\begin{tabular}{|c|c|c|c|c|}
\hline Sample/culture & Enzymatic activity & $\begin{array}{l}\text { Temperature } \\
\text { of maximum } \\
\text { activity }\left({ }^{\circ} \mathrm{C}\right)\end{array}$ & $\mathrm{Q}_{10}$ & $\begin{array}{l}\text { In situ } \\
\text { temperature } \\
\left({ }^{\circ} \mathrm{C}\right)\end{array}$ \\
\hline
\end{tabular}

Natural samples

Sampling site A

Sampling site A

Protease

Protease

75

2.23

10.1

Sampling site A

Sampling site A. 6:00

Sampling site A. 11:00 ${ }^{\mathrm{a}}$

Sampling site A. 16:00 ${ }^{\mathrm{a}}$

Sampling site A. 20:00 ${ }^{\mathrm{a}}$

Sampling site A. $24: 00^{\mathrm{a}}$

Protease

65

1.62

25.1

Protease

65

1.79

11.8

Protease

1.62

21.6

Protease

1.33

44.4

Protease

1.41

60.0

Sampling site A. $10 \mathrm{~cm}^{\mathrm{b}}$ 6:00

Protease

$1.35 \quad 39.4$

Sampling site A. $10 \mathrm{~cm}^{\mathrm{b}} 11: 00^{\mathrm{a}}$

Protease

$1.57 \quad 27.0$

Sampling site A. $10 \mathrm{~cm}^{\mathrm{b}} 16: 00^{\mathrm{a}}$

Protease

$1.72 \quad 30.8$

Sampling site A. $10 \mathrm{~cm}^{\text {b } 20: 00^{\mathrm{a}}}$

Protease

$1.45 \quad 29.7$

Sampling site A. $10 \mathrm{~cm}^{\text {b } 24: 00^{\mathrm{a}}}$

Protease

$1.58 \quad 34.4$

Protease

Protease

Protease

Protease

Protease

Protease

Protease

Protease

Protease

Protease

Glucosidase

Glucosidase

Sampling site A.

Cultures

E. coli

Brevibacillus strain 10

Protease

Protease

Protease

Ureibacillus strain 12

Glucosidase

Glucosidase

Glucosidase
1.57

1.63

1.73

1.73

1.91

1.48

1.28

1.42

40.4

36.3

16.3

13.4

23.9

18.6

20.4

16.7

$1.45 \quad 12.6$

$1.99 \quad 2.0$

$2.23 \quad 0.0$

$2.22 \quad 0.0$

$2.18 \quad 28.0$

$2.10 \quad 28.5$

$1.58 \quad 30.0^{\mathrm{c}}$

$2.6850 .0^{\mathrm{c}}$

$2.6850 .0^{\mathrm{c}}$

$1.8930 .0^{\mathrm{c}}$

$2.3150 .0^{\mathrm{c}}$

$1.56 \quad 50.0^{\circ}$ 


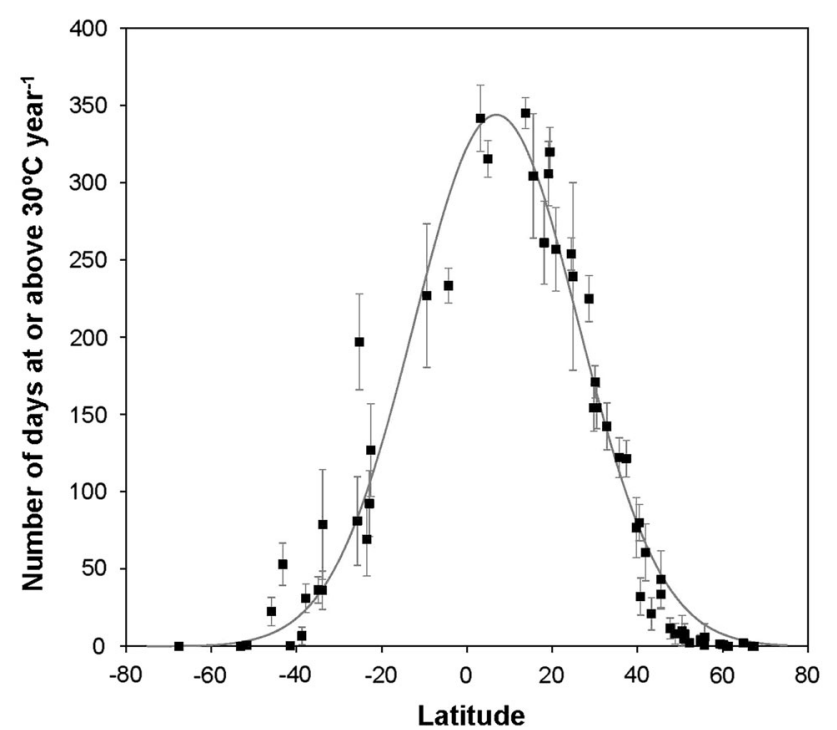

Fig. 2 Average of days reaching $30{ }^{\circ} \mathrm{C}$ and above per year as a function of latitude from $\mathrm{S}$ (negative values) to $\mathrm{N}$ (positive values). The Gaussian curve corresponds to the best fitting for the presented data set. Bars indicate SD

generally below $30{ }^{\circ} \mathrm{C}$ (Craine et al. 2010; Fierer et al. 2006; Ise and Moorcroft 2006; Townsend et al. 1992). Enzymatic activities in soil and sediment samples measured during the present study showed maximum rates at temperatures above $50{ }^{\circ} \mathrm{C}$. This is in agreement to early studies in soils reporting maximum enzymatic activity around $50{ }^{\circ} \mathrm{C}$ (Ladd and Butler 1972). A first consequence of these results is that high temperatures will lead to increased estimates of microbial extracellular enzymatic activity (i.e., depolymerisation of macromolecules). An exponential increase of microbial respiration versus temperature has been reported although high temperature values were previously considered above any real or predicted climate (Townsend et al. 1992). The presence in soils of active thermophilic bacteria (Marchant et al. 2002, 2008; Portillo et al. 2012) adds on to the finding of significant soil microbial activities during high temperature conditions. The hydrolysis of polymers and microbial activity at elevated temperatures show potential ecological and global relevance.

Results have shown an increase in the proteolytic and glucolytic activities under elevated temperatures. During this study, the activity estimated at $50-70{ }^{\circ} \mathrm{C}$ represented 4-8-fold the activity determined at $20-30{ }^{\circ} \mathrm{C}$, with an average around sixfold which corresponds to average $\mathrm{Q}_{10}$ values around 2 which were observed in these experiments. Considering that (1) at latitudes below $40^{\circ} \mathrm{N}$ and $40^{\circ} \mathrm{S}$ high temperatures are reached numerous days annually (Fig. 2) and (2) at these latitudes about half a day can show soil surface temperatures at or above $40{ }^{\circ} \mathrm{C}$ (Portillo et al. 2012), one could deduce the occurrence of higher microbial extracellular enzymatic activity at high temperatures than predicted from current estimates (Bradford et al. 2010; Conant et al. 2011; Craine et al. 2010; Gruber et al. 2004). Latitudes below $40^{\circ}$, from $\mathrm{N}$ to S, represent over $64 \%$ of Earth surface with corresponds to above half the land surface of our planet. These consequences of microbial extracellular enzymatic activity in soils and sediments can reach significant levels on a global scale, and they should be considered in future modeling and predictions at local and global scales. With those considerations, conservative estimates suggest that hydrolytic enzymatic activities at medium and low latitudes under elevated temperatures could represent a doubling of previous estimates on depolymerisation of macromolecules by microorganisms at these locations and above an additional $50 \%$ of current global estimates. Results indicate that the effect of high temperature conditions on microbial activity processing soil organic matter should be considered in future analyses and predictions on the role of microorganisms in soils.

Microbial enzymatic activity to depolymerise soil organic matter can be influenced by numerous factors (Conant et al. 2011; Davidson and Janssens 2006; Smith et al. 2008). Temperature is an important factor affecting microbial activity in soils and shows relationships with many biological, physical and chemical processes (Conant et al. 2011; Davidson and Janssens 2006). Some research have focused on the quality or degradability of organic matter in soils and the effects of climate change on its decomposition (Fierer et al. 2005; Smith et al. 2008; Wetterstedt et al. 2010). The temperature effects on availability and adsorption onto particles of soil organic matter is scarcely understood (Davidson and Janssens 2006). Recent debate has concluded that an increase in temperature should increase the rate of substrate desorption relative to adsorption of organic matter to mineral particles, meaning that substrate availability (i.e., the non-sorbed fraction) and solubility should be higher at warmer temperatures (Conant et al. 2011; Kalbitz et al. 2000). Besides, increasing water losses with temperature indicates a potential concentration of solutes while maintaining sufficient soil water moisture (Lee et al. 2008). These aspects would confer certain advantage to microbial depolymerisation under elevated temperatures with respect to moderate temperatures. Thus, climate warming, which is expected to result in more frequent extreme heat events and warmer summer seasons, should result in an increasing trend toward facilitating microbial extracellular enzymatic activity in soils.

\section{Conclusion}

In this study, microbial extracellular enzyme activity at elevated temperature has been shown to be of potential 
importance on the processing of organic matter in soils, above all, when considering global warming. The relevance of thermophilic processes could gain interest due to an expected increase in length and frequency of extreme heat events predicted for the next decades. This study identifies a novel mechanism and scenario within the multiple processes and environmental constraints that govern the microbial activity and depolymerisation of organic matter in a future where climatic disruptions are expected to become increasingly pronounced as a consequence of global warming.

Acknowledgments This work was supported by Grants from the Spanish Ministry of Science and Innovation, CGL2009-12328/BOS and CSD2009-00006, and the regional government of Andalusia (RNM2529 and BIO288). The participation of FEDER funds in these Projects is acknowledged.

\section{References}

Allison SD, Treseder KK (2008) Warming and drying suppress microbial activity and carbon cycling in boreal forest soils. Glob Change Biol 14:2898-2909

Asmar F, Eiland F, Nielsen NE (1994) Effect of extracellular-enzyme activities on solubilisation rate of soil organic nitrogen. Biol Fertil Soils 17:32-38

Bradford MA, Watts BW, Davies CA (2010) Thermal adaptation of heterotrophic soil respiration in laboratory microcosms. Glob Change Biol 16:1576-1588

Burton SG, Cowan DA, Woodley JM (2002) The search for the ideal biocatalyst. Nat Biotechnol 20:37-45

Chróst RJ (1992) Significance of bacterial ectoenzymes in aquatic environments. Hydrobiologia 243:61-70

Conant RT, Ryan MG, Ågren GI, Birge HE, Davidson EA, Eliasson PE, Evans SE, Frey SD, Giardina CP, Hopkins F, Hyvönen R, Kirschbaum MUF, Lavallee JM, Leifeld J, Parton WJ, Steinweg JM, Wallenstein MD, Wetterstedt JÅM, Bradford MA (2011) Temperature and soil organic matter decomposition ratessynthesis of current knowledge and a way forward. Glob Change Biol 17:3392-3404

Craine J, Spurr R, McLauchlan R, Fierer N (2010) Landscape-level variation in temperature sensitivity of soil organic carbon decomposition. Soil Biol Biochem 42:373-375

Curtis TP, Sloan WT, Scannell JW (2002) Estimating prokaryotic diversity and its limits. Proc Natl Acad Sci USA 99:10494-10499

Davidson EA, Janssens IA (2006) Temperature sensitivity of soil carbon decomposition and feedbacks to climate change. Nature 440:165-173

Fierer N, Craine JM, McLauchlan K, Schimel JP (2005) Litter quality and the temperature sensitivity of decomposition. Ecology $86: 320-326$

Fierer N, Colman BP, Schimel JP, Jackson RB (2006) Predicting the temperature dependence of microbial respiration in soil: a continental-scale analysis. Glob Biogeochem Cycles 20:1-10

Gonzalez JM, Portillo MC, Belda-Ferre P, Mira A (2012) Amplification by PCR artificially reduces the proportion of the rare biosphere in microbial communities. PLoS One 7:e29973

Gruber N, Friedlingstein P, Field CB, Valentini R, Heimann M, Richey JE, Lankao PR, Schulze ED, Chen CTA (2004) The vulnerability of the carbon cycle in the 21 st century: an assessment of carbon-climate-human interactions. In: Field C, Raupach $\mathrm{M}$ (eds) Toward $\mathrm{CO}_{2}$ stabilization: issues, strategies, and consequences. Island Press, Washington

IPCC (2007) Climate change 2007: contribution of working group I, II and III to the fourth assessment report of the intergovernmental panel on climate change. In: Solomon $\mathrm{S}$ et al (eds) Cambridge University Press, Cambridge

Ise T, Moorcroft PR (2006) The global-scale temperature and moisture dependencies of soil organic carbon decomposition: an analysis using a mechanistic decomposition model. Biogeochem 80:217-231

Jentsch A, Kreyling J, Beierkuhnlein C (2007) A new generation of climate change experiments: events, not trends. Front Ecol Environ 5:365-374

Kalbitz K, Sloinger S, Park JH, Michalzik B, Matzner E (2000) Controls on the dynamics of dissolved organic matter in soils: a review. Soil Sci 165:277-304

Kube M, Chemikova TN, Al-Ramahi Y, Beloqui A, Lopez-Cortez N, Guazzaroni M-E, Heipieper HJ, Klages S, Kotsyurbenko OR, Langer I, Nechitaylo TY, Lünsdorf H, Fernández M, Juárez S, Ciordia S, Singer A, Kagan O, Egorova O, Petit PA, Stogios P, Kim Y, Tchigvintsev A, Flick R, Denaro R, Genovese M, Albar JP, Reva ON, Martínez-Gomariz M, Tran H, Ferrer M, Savchenko A, Yakunin AF, Yakimov MM, Golyshina OV, Reinhardt R, Golyshin PN (2013) Genome sequence and functional genomic analysis of the oil-degrading bacterium Oleispira antarctica. Nat Commun 4:3156

Ladd JN, Butler JHA (1972) Short-term assays of soil proteolytic enzyme activities using proteins and dipeptide derivatives as substrates. Soil Biol Biochem 4:19-30

Lee RY, Porubsky WP, Feller IC, McKee KL, Joye SB (2008) Porewater biogeochemistry and soil metabolism in dwarf red mangrove habitats (Twin Cays, Belize). Biogeochem 87:181-198

Madigan M, Martinko JM, Parker J (2003) Brock biology of microorganisms. Prentice Hall, New Jersey

Marchant R, Banat IM, Rahman TJ, Berzano M (2002) The frequency and characteristics of highly thermophilic bacteria in cool soil environments. Environ Microbiol 4:595-602

Marchant R, Franzetti A, Pavlostathis SG, Tas DO, Erdbrugger I, Unyayar AH, Mazmanci MA, Banat IM (2008) Thermophilic bacteria in cool temperate soils: are they metabolically active or continually added by global atmospheric transport? Appl Microbiol Biotechnol 78:841-852

Marx M-C, Wood M, Jarvis SC (2001) A microplate fluorimetric assay for the study of enzyme diversity in soils. Soil Biol Biochem 33:1633-1640

McCalley CK, Sparks JP (2009) Abiotic gas formation drives nitrogen loss from a desert ecosystem. Science 326:837-840

Parmesan C, Yohe G (2003) A globally coherent fingerprint of climate change impacts across natural systems. Nature 421:37-42

Portillo MC, Santana M, Gonzalez JM (2012) Presence and potential role of thermophilic bacteria in temperate terrestrial environments. Naturwissenschaften 99:43-53

Santana MM, Portillo MC, Gonzalez JM, Clara I (2013) Characterization of new soil thermophilic bacteria potentially involved in soil fertilization. J Plant Nutr Soil Sci 176:47-56

Smith P, Fang CM, Dawson JJC, Moncrieff JB (2008) Impact of global warming on soil organic carbon. Adv Agron 97:1-43

Sokal RR, Rolhf FJ (1995) Biometry, 3rd edn. WH Freeman, New York

Stone MM, Weiss MS, Goodale CL, Adams MB, Fernandez IJ, German DP, Allison SD (2012) Temperature sensitivity of soil enzyme kinetics under $\mathrm{N}$-fertilization in two temperate forests. Glob Change Biol 18:1173-1184 
Tang X-Y, Wu B, Ying H-J, He B-F (2010) Biochemical properties and potential applications of a solvent-stable protease from the high-yield protease producer Pseudomonas aeruginosa PT121. Appl Biochem Biotechnol 160:1017-1031

Torsvik V, Øvreås L, Thingstad TF (2002) Prokaryotic diversitymagnitude, dynamics, and controlling factors. Science 296:1064-1066

Townsend A, Vitousek PM, Holland EA (1992) Tropical soils could dominate the short-term carbon cycle feedbacks to increased global temperatures. Clim Change 22:293-303

Velasco-Ayuso S, Guerrero MC, Montes C, López-Archilla AI (2011) Regulation and spatiotemporal patterns of extracellular enzyme activities in a coastal, Sandy aquifer system (Doñana, SW Spain). Microb Ecol 62:162-176

Wetterstedt JAM, Persson T, Agren GI (2010) Temperature sensitivity and substrate quality in soil organic matter decomposition: results of an incubation study with three substrates. Glob Change Biol 16:1806-1819

Whitman WB, Coleman DC, Wiebe WJ (1998) Prokaryotes: the unseen majority. Proc Natl Acad Sci USA 95:6578-6583 